\title{
Tumor-like lesions in the mantle of the mussel Modiolus difficilis from the Sea of Japan
}

\author{
L. N. Usheva*, N. A. Odintsova \\ Institute of Marine Biology, Far East Branch of Russian Academy of Sciences, Vladivostok 690041, Russia
}

\begin{abstract}
Two inner growths in the mantle beneath the epithelium were found in 1 of 1000 mussels Modiolus difficilis from Amursky Bay, Sea of Japan, within the city precincts of Vladivostok. Both growths were about $2000 \mu \mathrm{m}$ in maximal diameter in section and elevated slightly above the mantle surface. The mantle epithelium near the growths formed deep invaginations, and clusters of mucous cells were numerous beneath the epithelium. Histological and histochemical methods were employed. Two different kinds of growth were revealed. The off-white growth consisted of cells with thin granular or vesicular cytoplasm containing glucosaminoglycans, proteins and a small amount of neutral polysaccharides. Growth cells were pure white in color after treatment of preparations with $1 \% \mathrm{H}_{2} \mathrm{SO}_{4}$ and differed markedly from the mantle cells. The yellow growth consisted of large granular cells with neutral polysaccharides and proteins. Although growths were composed of different kinds of cells, they seemed to be derived from subepithelial mucous cells. This was supported by histological and histochemical staining reactions of some tumor and mantle epithelial cells. Mitotic indices (MI) of growths and subepithelial mucous cells were zero, $\mathrm{MI}$ of ciliated mantle epithelium reached $0.07 \%$. The lesions were areas of strongly altered mucous cells of mantle epithelium and were non-neoplastic.
\end{abstract}

KEY WORDS: Hyperplasia $\cdot$ Lesion $\cdot$ Mantle $\cdot$ Mitotic index $\cdot$ Mucous cells $\cdot$ Mussel

\section{INTRODUCTION}

It is known that spontaneous solid tumors are rarely revealed in natural populations of marine bivalves and most of them are localized in the mantle, foot, gills or siphon more often than in other organs (Pauley 1969, Khudoley \& Syrenko 1977, Sparks 1985). Probably, this localization is connected with more intimate contact with sea water. The mantle of bivalves is polyfunctional and concerned with the secretion of shell, sensory perception and the control of the water cleaning current in the mantle cavity. Histology, histochemistry and ultrastructure of the mantle have been studied well and different types of the cells have been revealed in the mantle folds of some bivalves (Galtsoff 1964, Hillman 1968, Bubel 1973, Stasek \& McWilliams 1973, Aleksandrova 1987, Morrison 1993, Garciagasca et al. 1994, Mikhailov et al. 1996, Reindl \& Haszprunar 1996).

\footnotetext{
·E-mail: inmarbio@mail.primorye.ru
}

To elucidate the defense function of the mantle surfaces of bivalves and estimate the frequency of solid tumors in mussel Modiolus difficilis, we began to examine mussels from urban-associated sites of the Sea of Japan. We revealed that tumor-like lesions of $M$. difficilis are also found in the mantle. In this paper the histology of 2 inner mantle lesions of 1 old mussel is described and cell sources of mantle lesions are discussed

\section{MATERIALS AND METHODS}

1000 mussels Modiolus difficilis (Modiolus kurilensis) were collected in spring-autumn 1990, 1991 and 1995 from Amursky Bay, Sea of Japan, within the city precincts of Vladivostok (Pervaya and Vtoraya Rechka Inlets, Tokarevsky cape), which is intensively polluted by industrial and domestic sewage and has high mollusk mortality (Tkalin et al. 1993). For histological analysis the material was fixed in phosphate buffered $10 \%$ neutral formalin ( $\mathrm{pH} 7.3$ to 7.4 ) containing $3 \% \mathrm{NaCl}$ 
for $36 \mathrm{~h}$ at $4^{\circ} \mathrm{C}$, followed by a wash in runnung tap water for $12 \mathrm{~h}$. Paraffin sections $5 \mu \mathrm{m}$ thick were stauned for routune histology with elther acid Mayer's hematoxylin and eosin, methylene blue, basıc fucsin, methylene blue-azure II-basic fucsin or Heidenhain's azan; for acid and neutral mucopolysaccharides, with Alcian blue/periodıc-acıd Shıff (PAS); for total proteins, with fast green at $\mathrm{pH}$ 2.2. In addition, we used $1 \% \mathrm{H}_{2} \mathrm{SO}_{4}$ to reveal calcium crystals (Pearse 1968). The mitotic index (MI) was determined in cells both of the growth (per 5000 cells) and protective epithelium (per 43000 cells) and also in associated subepithelial gland cells (per 5000 cells) upon examination of 5 to 10 tumor slides.

\section{RESULTS}

In February 1990 we found an off-white and a yellow inner small growth of spherical shape in the posterior mantle edge of 1 large mollusk (valve length $13 \mathrm{~cm}$; shell had some pustule lesions). Both growths were about 1700 to $2000 \mu \mathrm{m}$ in maximal diameter in section, lacked any capsule and were partially delimited from the mantle by fibers and hemal sinuses (Flg. 1). The mantle epithelium above the growths was low and non-convoluted; an edema occurred just beneath the epithelium of the off-white growth. The mantle epithelium near the growth was folded (formed deep invaginations) and clusters of subepithelial mucous cells were numerous (Figs. 1AC \& 2A-C). Three kinds of epithelial gland cell were 1dentified: (1) basophilic cells containing acid mucopolysaccharides or neutral mucopolysaccharides or mixed mucopolysaccharides; (2) some granular eosmophilic cells with proteins near the off-white growth and (3) large granular basophilic cells containing acid mucopolysaccharides near the yellow growth (Fig. 2, Table 1). The cross-sectional basophilic cells with acid-dominant mucus appeared as mimic basophilic hemocytes (Fig. 2C). However, on longitudinal sections these cells had necks extending to the epithelium and opening to the mantle surface, showing that they were obvious unicellular subepthelial glands (Fig. 2A, B). Growth cells differed or were similar to sub- and epithelial gland cells but were markedly different from the cells of the normal mantle

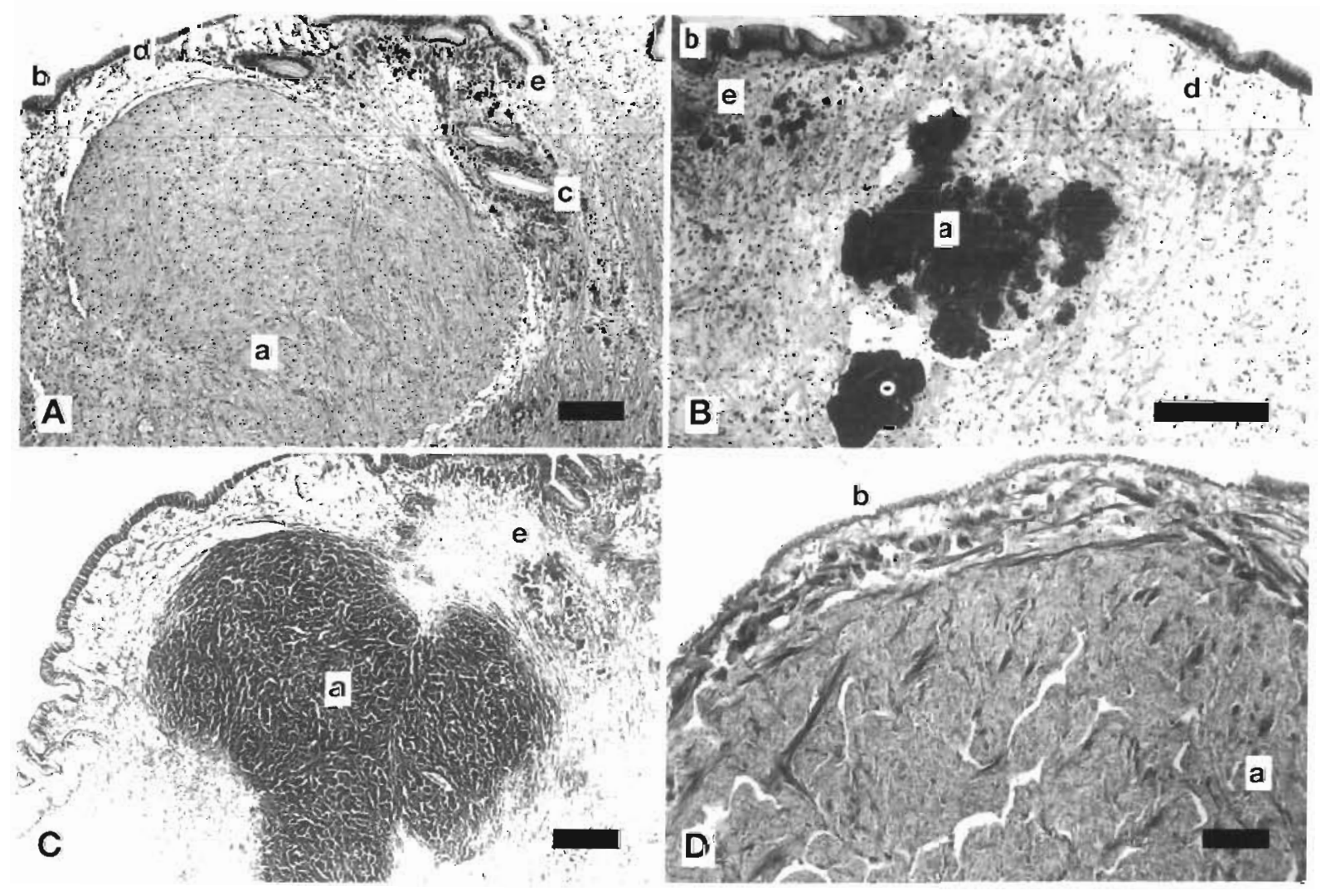

Fig 1 Modiolus difficils Histological structure and appearance of the growths in the mantle. (A-C) Off-white growth (longitudinal section), (D) yellow growth (cross section) (d) Growth cells, (b) mantle eprthelium, (c) cross section of the invaginations of the epithelium, (d) edema. (e) subepithelial gland cells. (A) H\&E, (B) methylene blue, (C) methylene blue-azure II-basic fucsin after processing by $1 \% \mathrm{H}_{2} \mathrm{SO}_{4}$, (D) Heidenhain's azan Scale bars $=200 \mu \mathrm{m}$ 


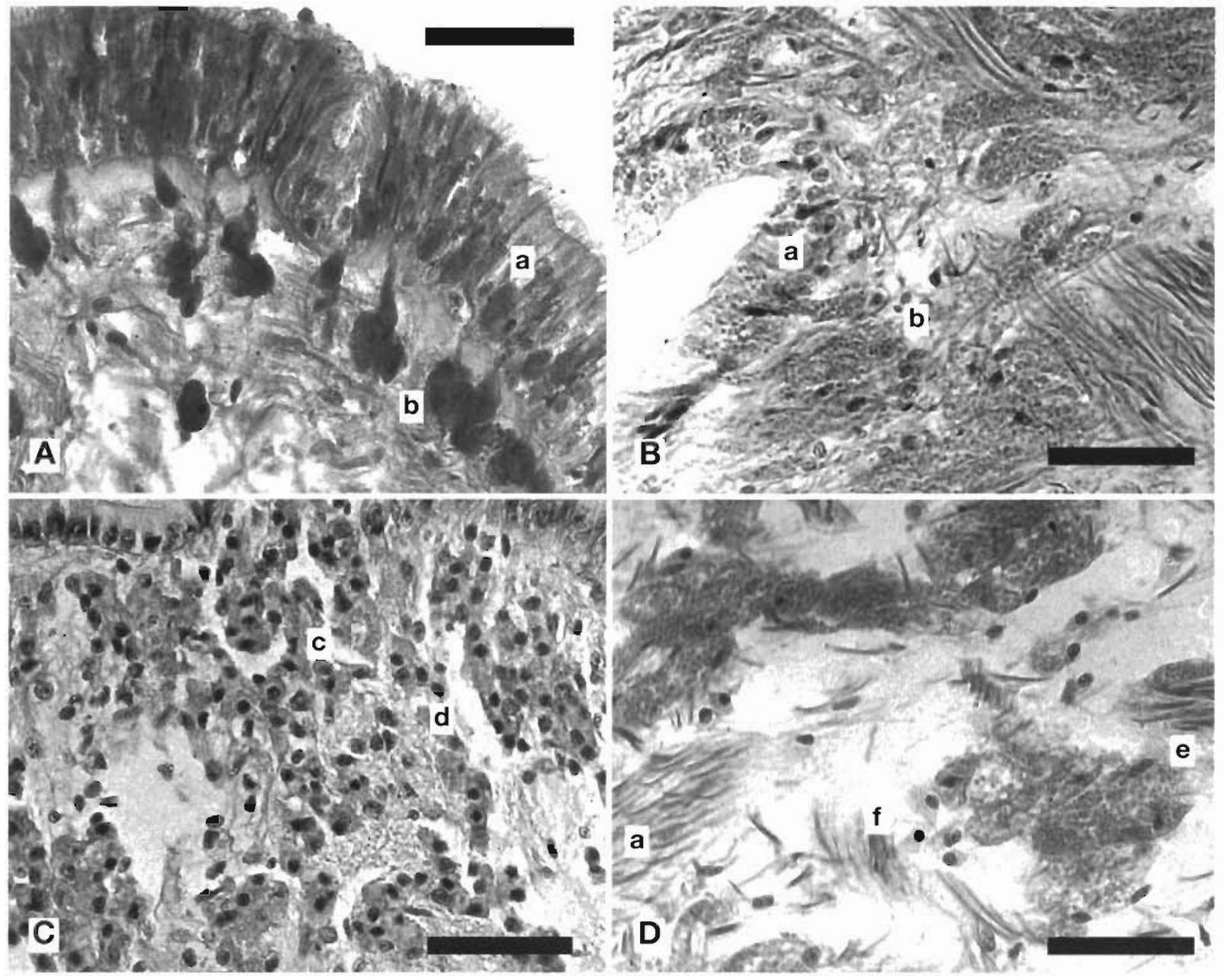

Fig. 2. Modiolus difficilis. Areas of the mantle $(A, B)$ near the off-white and (C, D) near the yellow growths. (a) Epithelial mucous cells, (b) subepithelial mucous cells with necks extending to the epithelium; cells that may be reacted with $1 \% \mathrm{H}_{2} \mathrm{SO}_{4}$ : (c) $\mathrm{cross}$ sectional subepithelial basophilic cells contained acid-dominant mucus after alcian blue/PAS staining and (d) cells resembling growth cells, (e) clumps of large granular cells in central area of the mantle similar to mucous cells, (f) hemocytes. (A) Methylene blue, (B) H\&E, (C) basic fucsin, (D) Heidenhain's azan. Scale bars $=50 \mu \mathrm{m}$

\section{Oif-white growth}

The growth consisted of cells with thin granular or vesicular cytoplasm, some muscle and collagen fibers and hemocytes (Fig. 3A, B). The cytoplasm of thin granular cells may be either modified into vesicular cytoplasm or destroyed. The cells with thin granular as well as vesicular cytoplasm contained diffuse gluco-

Table 1. Modiolus difficilis. Staining properties of the growth cells and mantle epithelial cells: $(+)$ present, $(-)$ not present, (n) not measured

\begin{tabular}{|c|c|c|c|c|}
\hline Reaction & $\begin{array}{l}\text { Off-white } \\
\text { growth cells }\end{array}$ & $\begin{array}{c}\text { Yellow } \\
\text { growth cells }\end{array}$ & $\begin{array}{l}\text { Subepithelial } \\
\text { mucous cells }\end{array}$ & $\begin{array}{l}\text { Intraepithelial } \\
\text { mucous cells }\end{array}$ \\
\hline Acid Mayer's hematoxylin &,+- &,+- &,,+++++- &,,+++++- \\
\hline Eosin & + &,+- &,+- &,+- \\
\hline Methylene blue & +++ & + & $++t$ & +++ \\
\hline Methylene blue-azure II-basic fucsin & +++ &,+++ & +++ & +++ \\
\hline Heidenhain's azan & $\mathrm{n}$ & blue & blue & blue \\
\hline Alcian blue &,+++ & + &,,+++++- &,,+++++- \\
\hline PAS &,-+ &,+++++ &,++++++ &,,+++++- \\
\hline Fast green at $\mathrm{pH} 2.2$ &,+++ & + & + & + \\
\hline
\end{tabular}



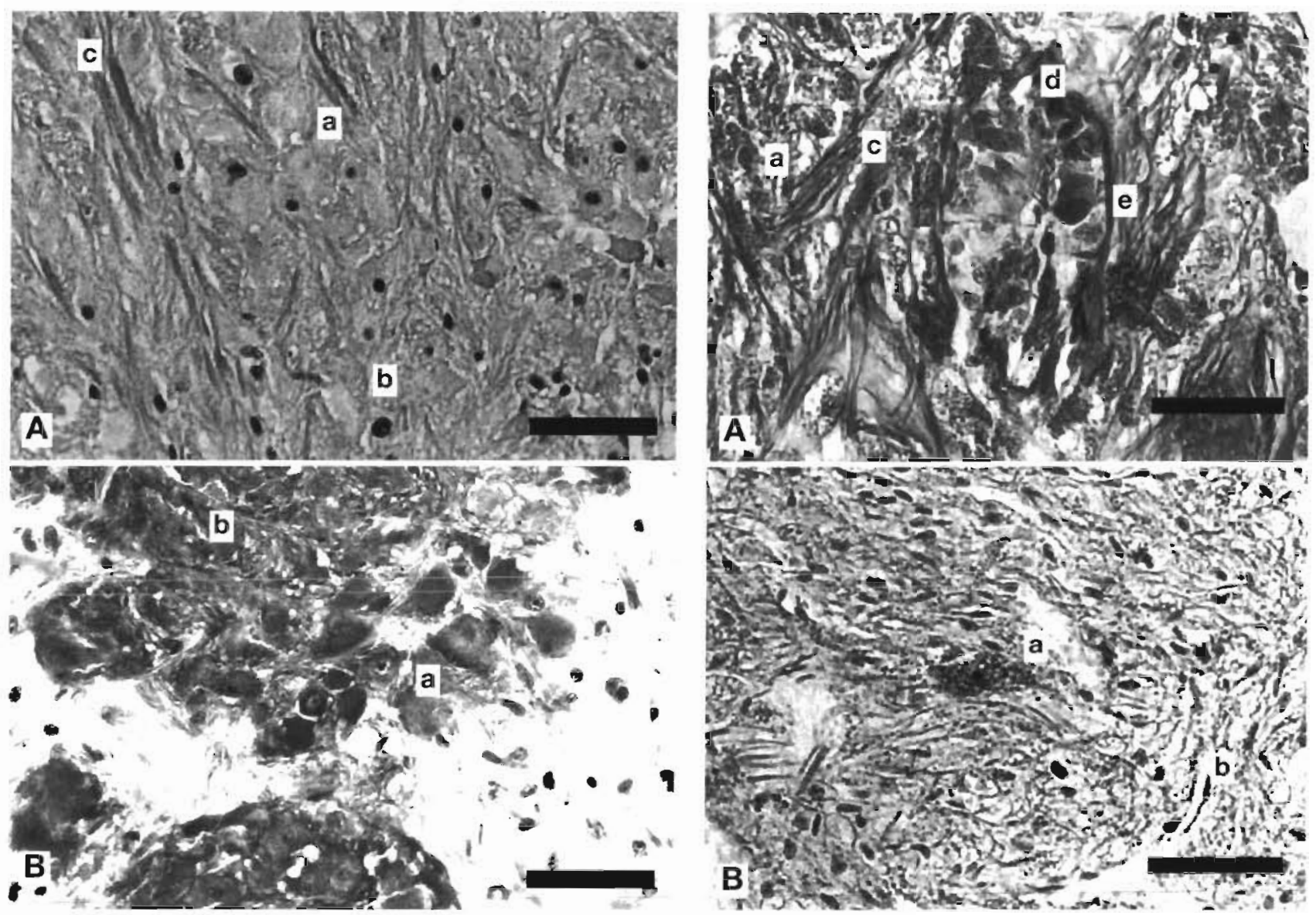

Figs. 3 \& 4. Modiolus difficilis. Cell composition of growth areas. Fig. 3. Off-white growth. (A) Center, (B) bottom; (a) thin granular cells, (b) cells with vesicular cytoplasm, (c) muscle and collagen fibers. (A) H\&E, (B) methylene blue. Scale bars $=50 \mu m$. Fig. 4 . Yellow growth. (A) Peripheral, (B) center parts; large granular cells with (a) intensively or (b) pale stained granules, (c) bundles of muscle and collagen fibers, (d) cross-sectional epithelium invaginations in the of mantle, (e) mucous cells. (A) Heidenhain's azan,

(B) basic fucsin. Scale bars $=50 \mu \mathrm{m}$

saminoglycans in moderate concentrations, some grains of neutral polysaccharides and a few proteins. Single damaged thin granular cells contained significant amounts of protein. The growth cells as epithelial and subepithelial mucous cells were intensively stained blue by methylene blue and metachromatically stained with methylene blue-azure II-basic fucsin in contrast to mantle connective cells and granular hemocytes (Table 1, Figs. 1B, C \& 3B). Calcium crystals were not found in the lesions. The growth and 3 small loci of mantle near the margin of the growth section were pure white, distinctly different from the color of mantle tissues after treatment of preparations with $1 \% \mathrm{H}_{2} \mathrm{SO}_{4}$. The cells of these mantle loci were arranged beneath epithelium invaginations among basophilic cells with acid-dominant mucus and cells resembling growth cells (Figs. $2 \mathrm{C} \& 3 \mathrm{~A}$ ). Like growth and mucous cells, they stained with methylene blue and methylene blue-azure II-basic fucsin (Fig. 1). In the other areas of the mantle, cells with thin granular or vesicular cytoplasm similar to those of the off-white growth were not found.

The cells within the lesions differed in size (20 to $90 \mu \mathrm{m}$ in diameter) and were larger than crosssectional subepithelial gland cells (20 to $40 \mu \mathrm{m}$ in diameter). Hypertrophy of some cells with vesicular cytoplasm was obvious. Cells had mainly 1 round frequently hyperchromic nucleus with 1 large nucleolus (Fig. 3). Some abnormal nuclei were found in the cells: deformed, bizarre and atypically large, also nuclei with micronuclei or with fragments of chromosome bridge and nuclei containing neutral polysaccharides or glucosaminoglycans.

\section{Yellow growth}

The growth consisted of the large granular cells staining lightly or negative with hematoxylin and eosine, easily with Heidenhain's azan in blue, and 
heavily with basic fucsin, and containing different amounts of granules with neutral polysaccharides + proteins (Figs. 1D \& 4A, Table 1). The cellularity of the inner center part of the growth was more than that of the outside part. Outside of the growth the cells mainly had intensively stained granules and formed strands among thick bundles of muscle and collagen fibers of the mantle. Hypertrophy of some cell nuclei and granules was marked. The cells of the inner center part of the growth were arranged in node-like structures and had mainly pale stained granules although some cells had intensively stained granules (Fig. 4B). The morphology and histochemistry of growth cells with many intensively stained granules were similar to those of the inter- and subepithelial large granular cells (Figs. 2B \& 4, Table 1). In the central area of the mantle near the epithelium invaginations were some loci of large granular cells (Fig. 2D) mimicking mucous large granular cells. Hemal spaces were well developed in this growth.

Mitotic indices (MI) of cells from the off-white and yellow growths, subepithelial mucous cells and epithelial cells of the outer side of the mantle were zero. MI of ciliate epithelium of the mantle inner side ranged from 0.03 to $0.07 \%$ and some premitotic cells were found in the off-white growth.

There were neither growth cells in the sinuses and vessels of the mantle nor pathogenic agents. There was a slight hemocyte infiltration of the mantle.

\section{DISCUSSION}

The subepithelial gland system of bivalves has been described in foot, mantle and palps in Mytilidae (List, 1902), in Grythea angulata (Leenhardt 1926) and in Anadara trapezia (Sullivan 1961). Beninger and coworkers (Beninger et al. 1991, Beninger \& St-Jean 1997) describe this system in different organs of the mantle cavity only in Mytilus edulis. The results of the present study show that there is a subepithelial gland system also in the mantle of mussel Modiolus difficilis (kurilensis). Tumor-like lesions in $M$. difficilis seem to be connected with hyperplasia of mucous cells and growths appear to be derived from different kinds of subepithelial gland cells of the mantle epithelium. This assumption is attested to by some similar staining reactions and the morphology of some tumor and mantle epithelial cells (Figs. 1B, C, 2A, C, 3B \& 4A, Table 1).

\section{Ofi-white growth}

The similarity of the off-white growth cells to epithelial mucous cells is shown by the similar cell content and staining reaction to methylene blue and methylene blue-azure II-basic fucsin (Figs. 1B, C, 2A \& 3B, Table 1). The cells localized near the growth which reacted with $\mathrm{H}_{2} \mathrm{SO}_{4}$ similar to growth cells may indicate too the source of the tumor, i.e. subepithelial gland cells or connective cells (Fig. 2C). In general, the morphology of thin granular cells is markedly different from that of epithelial gland cells (Fig. 3). Growth cells seem to resemble either mammary granular-cell Abrikossoff's myoblastoma (Willis 1967) or changed connective (storage) cells or granular hemocytes. However, these cells are not muscle or storage adipogranular (ADG) cells because they contain mainly acid mucosubstances (glucosaminoglycans) and small amounts of proteins and neutral polisaccharides.

\section{Yellow growth}

The yellow growth of the mussel seems to develop also as a result of the hyperplasia of subepithelial cells since the cells outside and 2 cells in the center inner part of the growth display a clear homology with granular mucous cells of mantle epithelium (Figs. 2B \& 4) and also contain mucus. In all probability, growth cell granules could not longer be stained by hematoxylin and eosin or these granules were destructed.

These subepithelial granular cells in the mussel Modiolus difficilis resemble granular cells in the subepithelial layer of the mantle of pearl oyster described by Suzuki \& Mori (1991) as connective (storage) cells. However, we support the assumption of Fisher (1992) that the cells of Suzuki \& Mori could actually be mucous cells of oyster.

A cause of mussel cell hyperplasia is unknown. Probably, it appears as a compensatory response to increased functional demands in areas with high water pollution (Tkalin et al. 1993). Mucous cells of organs in the bivalve mantle cavity were found to be able to agglutinate bacteria and different foreign particles and to inhibit metal absorption or depuration of heavy metals (Lobel 1981, Fisher 1992, Sze \& Lee 1995). Production of mucus was shown to increase under pollution stress (Scott \& Major 1972, Sunila 1984, Sze \& Lee 1995).

In addition, a large number of mucous cells in the outer epithelium might be connected with the production of the matrix of the shell, since there were pustule lesions on the mussel shell. The presence of collagen in the yellow growth, edema over off-white growth and slight hemocyte infiltration of the mantle suggests also a chronic inflammation of the mantle that may be the other cause of mussel gland hyperplasia. Lichtenfels et al. (1996) confirmed that water pollution resulted in a chronic inflammatory process in fish gills, epithelial 
hyperplasia and hypersecretion of alcian-blue-positive mucin on the epithelial surface.

A mantle disease was described for the clam Macoma balthica by Pekkarinen (1993). However, the hyperplastic growth of Modiolus difficilis differed from that of $M$. balthica in the location, the form, the size, the variations in amounts of mucus and also in the pigmentation of the mantle epithelium above the growth.

It is also of interest whether there is a connection between the emergence of growths and the formation of the deep invaginations of mantle epithelium. Perhaps these invaginations are a reactive response of mantle epithelium common among sick mollusks. Deeply plicated epithelium was observed also by Pauley (1969) in mollusks with polypoid growths. Such deep invaginations are absent in the mantle of healthy mussels. Epithelial deep invaginations and the subepithelial gland system of the mussel mantle probably clear up the appearance of clusters of mucous ceìs in center parts of the mussel mantle.

Mitotic activity of growth cells and subepithelial mucous cells was zero. Moreover, among cells of the off-white growth, cells at the preprophasa stage were found. This permitted the assumption that they can proliferate. In a few interphase cells of the off-white growth, indications of previous mitotic anomalies were detected. It is possible that this growth at the earlier stages developed from mitotic anomalies. However, tumor-like lesions seemed to be non-neoplastic, but as areas of strongly altered mucous cells of mantle epithelium.

Acknowledgements. The authors extend their thanks to Prof. P. A. Motavkin, Medical Institute, Vladivostok, and Dr V. V Isaeva, Ins. Marine Biology, Vadivostok, for critical comments and discussion of our work.

\section{LITERATURE CITED}

Aleksandrova OA (1987) Histochemical and ultrastructural study of the mantle edge epithelium in two bivalve mollusc species Margaritana margaritifera and Anodonta cygnea. Tsitologiya 29:995-1001 (in Russian)

Beninger PG, Le Pennec M, Donval A (1991) Mode of particle ingestion in five species of suspension-feeding bivalve molluscs. Mar Biol 108(2):255-261

Beninger PG, St-Jean SD (1997) The role of mucus in particle processing by suspension-feeding marine bivalves: unifying principles. Mar Biol 129:389-397

Bubel A (1973) An electron-microscope investigation of the cells lining the outer surface of the mantle in some marine molluscs. Mar Biol 21:245-255

Fisher WS (1992) Occurrence of agglutinins in the pallial cavity mucus of oysters. J Exp Mar Biol Ecol 162:1-13

Galtsoff PS (1964) The American oyster Crassostrea virginica (Gmelin). Fish Bull 64:74-111

Garciagasca A, Ochoabaez RI, Betancourt M (1994) Micro- scopic anatomy of the mantle of the pearl oyster Pinctada mazatlanica (Hanley, 1856). J Shell Res 13(1):85-91

Hillman RE (1968) Histochemistry of mucosubstances in the mantle of the clam Mercenaria mercenaria I. A glycosaminoglycan in the first marginal fold. Trans Am Microsc Soc $87(3): 361-367$

Khudoley VV, Syrenko OA (1977) Tumors in molluscs. Adv Modern Biol 84:128-137 (in Russian)

Leenhardt H (1926) Quelques études sur 'Grythea angulata' Ann lnst Oceanogr Paris 3:1-89

Lichtenfels AJFC, Lorenzi G, Guimaraes ET, Macchione M Saldiva PHN (1996) Effects of water-pollution on the gill apparatus of fish. J Comp Pathol 115:47-60

List T (1902) Die Mytiliden. Fauna und Flora des Golfes von Neapel und der angrenzenden Meeres-Abschnitte Monogr 27, Zoologische Station zu Neapel, Friedlander \& Sohn, Berlín

Lobel P (1981) Zn in mussels from an iron pipe. Mar Pollut Bull 12:410-411

Mikhailov AT, Torrado M, Mendez J, Lopez MJ (1996) Annual cycle of expression of connective-tissue polypeptide markers in the mantle of the mussel Mytilus galloprovincialis. Mar Biol 126(1):77-79

Morrison CM (1993) Histology and cell ultrastructure of the mantle and the mantle lobes of the eastern oyster, Crassostrea virginica (Gmelin)--a summary atlas. Am Malac Bull 10:1-24

Pauley GB (1969) A critical review of neoplasia and tumorlike lesions in molluscs. Natl Cancer Inst Monogr 31 509-539

Pearse AGE (1968) Histochemistry. Theoretical and applied. Little, Brown and Co, Boston

Pekkarinen M (1993) Neoplastic diseases in the Baltic Macoma balthica (Bivalvia) of the Finnish coast. J Invertebr Pathol 61:138-146

Reindl S, Haszprunar G (1996) Fine structure of caeca and mantle of arcoid and limopsoid bivalves (Mollusca: Pteriomorpha). Veliger 39(2):101-116

Scott DM, Major CW (1972) The effect of copper (II) on survival, respiration, and heart rate in the common blue mussel, Mytilus edulis. Biol Bull 143:679-688

Sparks AK (1985) Synopsis of invertebrate pathology. Exclusive of insects. Elsevier Science, Amsterdam

Stasek CR, McWilliams WR (1973) The comparative morphology and evolution of the molluscan mantle edge. Veliger 16:1-19

Sullivan GE (1961) Functional morphology, microanatomy, and histology of the 'Sydney cockle' Anadara trapezia (Deshayes) (Lamellibranchia: Arcidae). Austral J Zool 9: $219-257$

Sunila I (1984) Copper- and cadmium-induced histological changes in the mantle of Mytilus edulis L. (Bivalvia). Limnologica 15:523-527

Suzuki $\mathrm{T}$, Mori $\mathrm{K}$ (1991) Immunolocalization and in vitro secretion of hemolymph lectin of the pearl oyster, Pinctada fucata martensii. Zool Sci 8:23-29

Sze PWC, Lee SY (1995) The potential role of mucus in the depuration of copper from the mussel Perna viridis (L.) and Septifer virgatus (Wiegmann). Mar Pollut Bull 31(4-12): 390-393

Tkalin AV, Belann TA, Shapovalov EN (1993) The state of the marine environment near Vladivostok, Russia. Mar Pollut Bull 26(8):418-422

Willis RA (1967) Pathology of tumours. Appleton-CenturyGrofts, New York, p 760-763 